\title{
Chemical, phytochemical and functional properties of selected seeds' flours
}

\author{
Olorode Omobolanle O. ${ }^{1,}$, , Idowu Michael A. ${ }^{2}$, Bamgbose Adefunke ${ }^{1}$, Ayano Adeola E. ${ }^{3}$ \\ ${ }^{1}$ Department of Food Technology, Moshood Abiola Polytechnic, P.M.B. 2210, Abeokuta, Ogun State, Nigeria \\ ${ }^{2}$ Department of Food Science and Technology, Federal University of Agriculture, P.M.B. 2240, Abeokuta, Ogun State, Nigeria \\ ${ }^{3}$ Central Teaching and Research Laboratory, Bells University of Technology, Ota, Ogun State, Nigeria
}

\section{Email address:}

omobolanleolorode@yahoo.com (Olorode O. O.), idowumchl@gmail.com (Idowu M. A.), funkebamgbose51@gmail.com (Bamgbose A.), adeolaayano@gmail.com (Ayano A. E.)

\section{To cite this article:}

Olorode Omobolanle O., Idowu Michael A., Bamgbose Adefunke, Ayano Adeola E.. Chemical, Phytochemical and Functional Properties of Selected Seeds' Flours. International Journal of Nutrition and Food Sciences. Vol. 3, No. 6, 2014, pp. 572-578.

doi: $10.11648 /$ j.ijnfs.20140306.23

\begin{abstract}
This study was conducted to investigate qualities of benoil (Moringa oleifera), melon, water melon (Citrullus lanatus L.), pear and pawpaw (Carica papaya) seeds' flours with a view of harnessing them for consumption and possible industrial usage. All the seeds were manually separated from fruit pulps / pod, cleaned, washed with distilled water, air dried, shelled manually, sun dried and then grinded to flours. Chemical contents and functional properties of the resulting seed's flours were determined using standard methods. The results of the proximate and mineral composition indicated that all the seeds' flours contained considerable amounts of protein, fat, carbohydrate, ash, crude fibre, $\mathrm{Ca}, \mathrm{Na}, \mathrm{Fe}$ and $\mathrm{P}$ which made them potentials food supplements/food processing especially benoil (Moringa oleifera) and pawpaw seeds' flours. The result shows that watermelon seed flour ranked the highest in terms of all the phytochemical contents determined except its saponin content which was low. Melon seed's flour was low in saponin and tannin contents while its flavonoids and alkaloids contents were high. Saponin content of benoil seed's flours was also high compare to other seeds' flours tested. The tannin and flavonoid contents of benoil seed flour were low while the alkaloids content shows to be low in melon seed flour. However, the cyanide content of all the seeds' flours examined were low generally which shows the seeds' flours are expected to be save for consumption. There were significant $(\mathrm{p}>0.05)$ differences between the samples for all the phytochemical content determined. The seeds' containing all these phytochemicals show that they are highly medicinal and is good for human consumption especially watermelon and benoil (Moringa oleifera) seeds' flours. Also, the investigation showed that all the flours are characterized with good functional properties which mean they could be incorporated into food or use for industrial purpose most especially in infant food formulation. These qualities are indications that great potential exist for these seeds instead of throwing them away as waste after consuming the fruit pulp.
\end{abstract}

Keywords: Benoil Seed, Saponin, Protein, Pawpaw Seed's Flour, Calcium

\section{Introduction}

One of the most common problems in food processing is the disposal of the sub-products generated [1]. This waste material produces ecological problems related to the proliferation of insects and rodents and economical burden because of transportation to repositories, therefore strategies for the profitable use of these materials are needed.

In the food processing industry, edible portions of fruits are processed into products such as puree, canned slices, juice and pickles, whereas seeds are often discarded as waste since it is not currently utilized for commercial purposes [2] whereas [3] stated that seeds are promising source of useful compounds because of their favorable technological or nutritional properties. Papaya seeds are currently waste products as it is often discarded after eaten or processing. The seeds constitute $22 \%$ of the waste from papaya puree plant [4]. Papaya seeds are recently gaining importance due to its medicinal value, since it had been used recently in curing sickle cell diseases, poisonous related renal disorder [5] and 
as anti-helminthes [6]. Also, increasing growth of benoil powder, watermelon juice, pear jam and melon processing industries which results in the production of large quantities of their seeds as by-products, necessitate the determination of the potential of these seeds for human and/or animal diets. Adequate results on the potentials of these seeds such as their chemical (essential nutrient), phytochemicals and functional properties will create possibility for their use in food processes. Phytochemical are the non-nutritive plant chemicals that have protective or disease preventing properties [7-9] while functional properties (solubility, foamability and oil absorption capacity etc.) are the intrinsic physicochemical characteristics which may affect the behaviour of food systems during processing and storage. Functionality of a food is the property of a food ingredient, apart from its nutritional value, that has a great impact on its utilization. Reports made on some individual lesser known seeds and fruits indicated that they could be good sources of nutrient for both man and livestock $[10,11]$.

However, in order to create more report on the importance of usually discarded seeds it is necessary to assess the qualities of pawpaw, benoil, watermelon, melon and pear seeds. Therefore, the aim of this research work is to evaluate the chemical, phytochemical and functional properties of pawpaw seeds, benoil (Moringa oleifera), melon, watermelon and pear seeds' flours with a view of harnessing them for consumption and possible industrial usage

\section{Materials and Methods}

\subsection{Source of Materials}

The materials used for this research work; Pawpaw (Carica papaya L.) fruits, fresh watermelon (Citrullus vulgaris) fruits and melon (Cucumis melo) seeds were obtained from Lafenwa market in Abeokuta, Ogun State, Nigeria. Pear (Pyrus communis) fruits were obtained from Iyana Oba, Lagos State, Nigeria while benoil (Moringa oleifera) seed pods were obtained from a local farm in Oke Ata, Abeokuta, Ogun State, Nigeria

\subsection{Methods}

\subsubsection{Preparation of Materials}

All seeds were manually separated from fruit pulps/pod, cleaned, washed with distilled water, air dried, shelled manually to remove seed coats and dried using sun drying method for one week. They were sorted to remove bad ones, shelled, grinded with a laboratory blender, packed in an air tight container and stored ready for further analysis.

\subsection{Chemical Analysis}

\subsubsection{Determination of Proximate Composition}

The moisture, ash, crude fiber and fat (ether extract) contents were determined using a standard method [12]. Nitrogen content was determined using micro- kjeldahl and converted to crude protein $(\mathrm{N} x$ 6.25) [12]. Meanwhile the carbohydrate content was calculated by difference.

\subsubsection{Determination of Mineral Content}

The Iron content was measured colorimetrically at $480 \mathrm{~nm}$ using the method of [13]. For the calcium content, the reading of concentration was done on a spectrophotometer (AAS) while the method used for sodium content determination was flame photometric. The zinc and Phosphorus contents were also determined. All these parameters were determined according to the method of [13]

\subsubsection{Determination of Phytochemicals}

Alkaloid was determined by the alkaline precipitation gravimetric method described by [14] and Flavonoid was determined according to the method of [14]. The determination of tannin contents was done at $0.2 \mathrm{~g}$ of finely ground sample. Saponin was determined by adding $20 \mathrm{ml}$ of $20 \%$ aqueous ethanol to $10 \mathrm{~g}$ of the ground sample and agitated with a magnetic stirrer for $12 \mathrm{hrs}$ at $55^{\circ} \mathrm{C}$.

\subsubsection{Determination of Functional Properties}

The Water absorption capacity was determined according to the method of [15]. The result was expressed as a percentage of water absorbed by the blends on $\% \mathrm{~g} / \mathrm{g}$ basis. (Density of water was assumed to be $1 \mathrm{~g} / \mathrm{ml}$ ). The method described by [16] was used to determine the swelling capacity while the solubility was calculated after the determination of swelling capacity as per $100 \mathrm{~g}$ of starch on dry basis. $5 \mathrm{ml}$ of aliquot of the supernatant was dried to a constant weight at $120^{\circ} \mathrm{C}$. The residue obtained after drying represents the amount of starch solubilized in water using the method of [16]. The procedure of [17] was used to determine packed and loosed bulk density (PBD \& LBD). The Least gelation concentration was determined using the method of [18]. It was taken as the least concentration when the sample from the inverted test tube did not fall or slip. Oil absorption capacity was also determined using standard method.

\subsection{Statistical Analysis}

Analyses were done in triplicates and the mean value determined in each case. Data obtained were subjected to appropriate statistical analysis (SPSS 17.0) and the means were separated by Duncan Multiple Range Test where significant difference occurs.

\section{Results and Discussion}

\subsection{Result of the Chemical Contents of Ben Oil (Moringa oleifera), Water Melon, Pear, Pawpaw and Melon Seeds' Flours}

The results of the proximate and mineral composition of the seeds' flours examined are shown in tables 1 and 2 . It could be observed from table 1 that there were significant $(p \leq 0.05)$ differences among the studied seeds' flours in their contents of protein, fat, crude fibre, ash, moisture and carbohydrate. As regards proteins which are essential component of the diet needed for survival of animals and humans and of which basic function in nutrition is to supply adequate amounts of required amino acids [19]; watermelon, 
melon and benoil seed's flours contained significantly ( $\mathrm{p} \geq$ $0.05)$ higher levels $(16.30-31.04 \%)$ than other seed flours examined and it was also higher than $24.69 \%$ and $20.00 \%$ obtained for unfermented groundnut and sesame seed by [20] and [21] respectively. It is in agreement with the fact that watermelon seeds are source of protein [22]. The high protein content of the flours has a good implication in a society with high protein deficiency and will no doubt complement protein from cereals and other plant foods in the diets of Nigerians.

Lipids are essential because they provide the body with maximum energy; approximately twice that for an equal amount of protein or carbohydrate and facilitate intestinal absorption and transportation of fat-soluble vitamins A, D, E and $\mathrm{K}$ [23]

These same seeds' flours (watermelon, melon and benoil) also had the higher levels in terms of fat (12.91-21.25\%), which reflect the importance of such seeds for oil production like peanut and soybeans seeds. These results are in agreement (though lower) with the reports of [24-26] and it is also in agreement that watermelon seeds are good source of oil [22] and a source of edible vegetable oil if well prepared and hence could complement conventional vegetable oil which are expensive. Although those (pawpaw \& pear seeds' flours) with low oil content are relegated as a source of oil commercially, they can be recommended as part of weight reducing diets. This could be the one of the reason why researchers recommends pears seeds' flours for the obese and diabetic patients.

According to [27], fibre helps in the maintenance of human health and has been known to reduce cholesterol level in the body. Fibre diets promote the wave-like contraction that moves food through the intestine. High fibre food expands the inside walls of the colon, easing the passage of waste, thus making it an effective anti-constipation. It also lowers cholesterol level in the blood, reduce the risk of various cancers, bowel diseases and improve general health and well being. Presence of high crude fibre improves glucose tolerance and is beneficial in treating maturity on set diabetics [27]

From table 1 it could be seen that pawpaw seeds had the highest amount of crude fibre (5.88\%) which is although lower compared to $11.88 \%$ reported for fluted pumpkin by [28]. Melon and watermelon seed's flour could also be considered as a good source of dietary fibre next to pawpaw seed's flour while benoil and pear seeds' flours showed the lowest dietary fibre contents. The general low levels of fibre in the seeds' flours evaluated may be desirable in their incorporation in weaning diets since emphasis has been placed on the importance of keeping fibre intakes low in the nutrition of infants and pre-school children [27]. High fibre levels in weaning diet can lead to irritation of the gut mucosa, reduced digestibility, vitamin and mineral availability [27].

Percentage ash of sample gives an idea about the inorganic content of the samples from where the mineral content could be obtained [29]. Regarding the ash content in tested seeds' flours, pawpaw also exhibit higher amount (9.56\%) which was higher compare to $6.51 \%$ reported for jack bean by [30] and $7.86 \%$ reported for $S$. innocua seed's flour [29], followed by melon (although low) and watermelon seeds' flours while the content was very low in the rest. Samples with high percentages of ash contents are expected to have high concentrations of various mineral elements, which are expected to speed up metabolic processes and improve growth and development [29].

The moisture content of pear, watermelon and pawpaw seeds' flours was found to be within $6.39 \%$ to $8.20 \%$. These values were higher compared to $5.7 \%$ reported for by [31] but similar to $6.46 \%$ and $6.56 \%$ reported for cottonseeds and sunflower seeds [32]. Meanwhile benoil and melon had low moisture content i.e. $4.77 \%$ and $5.58 \%$ respectively, which are within the acceptable range for a good keeping period. The relatively low moisture content is an indication that these seeds' flours will have high shelf life especially when properly packaged against external conditions [33].

Table 1. Result of the proximate contents of ben oil (Moringa oleifera), water melon, pear, pawpaw and melon seeds'flours.

\begin{tabular}{|c|c|c|c|c|c|c|}
\hline Samples & Moisture \% & Ash \% & Protein \% & Crude fibre \% & Fat $\%$ & СНО \% \\
\hline Benoil Seed's Flour & $4.77^{\mathrm{a}}$ & $1.71^{\mathrm{a}}$ & $31.04^{\mathrm{c}}$ & $1.17^{\mathrm{a}}$ & $21.25^{\mathrm{c}}$ & $40.06^{\mathrm{b}}$ \\
\hline Watermelon Seed's flour & $6.95^{\mathrm{d}}$ & $3.24^{\mathrm{c}}$ & $16.30^{\mathrm{b}}$ & $2.24^{\mathrm{c}}$ & $12.91^{\mathrm{c}}$ & $58.36^{\mathrm{d}}$ \\
\hline Pear Seed' flour & $8.20^{\mathrm{e}}$ & $2.97^{\mathrm{b}}$ & $5.93^{\mathrm{a}}$ & $1.38^{\mathrm{b}}$ & $3.05^{\mathrm{a}}$ & $78.47^{\mathrm{e}}$ \\
\hline Melon Seed's flour & $5.58^{\mathrm{b}}$ & $3.51^{\mathrm{d}}$ & $30.97^{\mathrm{c}}$ & $2.35^{\mathrm{c}}$ & $14.28^{\mathrm{d}}$ & $43.31^{\mathrm{c}}$ \\
\hline
\end{tabular}

* Values are means of triplicate determination

* Means on the same column with different superscripts are significantly different $(\mathrm{P} \leq 0.05)$

Table 2. Result of the mineral contents of benoil, watermelon, pear, pawpaw and melon seed flour.

\begin{tabular}{|c|c|c|c|c|}
\hline Samples & Calcium (\%) & Sodium (\%) & Iron (ppm) & Potassium (\%) \\
\hline Benoil Seed's flour & $4.14^{\mathrm{a}}$ & $0.106^{\mathrm{a}}$ & $181.50^{\mathrm{b}}$ & $0.021^{\mathrm{b}}$ \\
\hline Watermelon Seed's flour & $5.30^{\mathrm{d}}$ & $0.124^{\mathrm{c}}$ & $265.50^{\mathrm{c}}$ & $0.019^{\mathrm{b}}$ \\
\hline Pear Seed's flour & $5.01^{\mathrm{c}}$ & $0.104^{\mathrm{a}}$ & $371.00^{\mathrm{e}}$ & $0.005^{\mathrm{a}}$ \\
\hline Pawpaw Seed's flour & $5.28^{d}$ & $0.113^{\mathrm{b}}$ & $162.50^{\mathrm{a}}$ & $0.019^{\mathrm{b}}$ \\
\hline Melon Seed's flour & $4.93^{\mathrm{b}}$ & $0.117^{\mathrm{b}}$ & $317.00^{\mathrm{d}}$ & $0.007^{\mathrm{a}}$ \\
\hline
\end{tabular}

* Values are means of triplicate determination

* Means on the same column with different superscripts are significantly different $(\mathrm{P} \leq 0.05)$ 
The carbohydrate content obtained was within $37.67 \%$ to $78.47 \%$ which were higher compared to $26 \%$ reported for sunflower [32] and comparable with the $71.94 \%$ reported for $S$. innocua seed's flour. Which means some of the seeds most especially pear and watermelon seeds' flours can be considered as a potential carbohydrate source when compared to the content of conventional source like cereals $72-90 \%$ carbohydrate [34] and could be good supplements to scarce cereal grains as sources of energy in feed formulation. The carbohydrate contents of pawpaw and benoil seeds' flours were low; 37 and $40 \%$ respectively. According to [34], samples with low carbohydrate content might be ideal for diabetic and hypertensive patients requiring low sugar diets.

In terms of Mineral content (table 2), calcium which help in regulation of muscle contractions transmit nerve impulses and help in bone formation and are also required by children, pregnant and lactating woman for bones and teeth development was higher in watermelon and pear seeds' flours; 5.30 and $5.20 \%$ respectively but low in benoil and melon seeds' flours the values obtained were lower than $11.6 \%$ reported for $C$. millenii seed by [29].

Potassium content of the tested seeds' flours ranged between 0.005 and $0.021 \%$ in which benoil contained the highest and pear seeds' flours contained the lowest. These values compared favourably with $0.0213 \%$ in pineapple pulp [35].

Iron is said to be an important element in the diet of pregnant women, nursing mothers, infants convulsing patients and elderly to prevent anaemia and other related diseases [36]. The recommended daily allowance of iron for men is $7 \mathrm{mg} /$ day and $12-16 \mathrm{mg}$ /day for women during pregnancy [37].

Iron $(\mathrm{Fe})$ ranged between 162 ppm for pawpaw seeds' flour and $371 \mathrm{ppm}$ in pear seeds' flour which was the highest. Appreciable higher values were also recorded for melon and watermelon seeds' flours while $181 \mathrm{ppm}$ was recorded for benoil. Sodium is an important source of electrolytes within the body. Sodium of the tested seeds' flours ranged between 0.104 and $0.124 \%$ which is higher than the $0.079 \%$ in $S$. innocua seed [29].

\subsection{Result of the Phytochemical Contents of Ben Oil (Moringa oleifera), Water Melon, Pear, Pawpaw and Melon Seeds' Flours}

Phytochemicals are non-nutritive chemicals that occur naturally in plants. Certain phytochemicals (such as saponins) were reported to have pharmacologically active effects on seed's flour [38]. These phyto-constituents were reported as antibiotic principles of plants and they offer benefits (prevent cell damage and fight infections) in plants and animals when ingested by them in food [39].

Certain phytochemicals have anti-nutritional properties (side effects), when ingested in excess. Cyanide and tannins bind essential minerals such as calcium, iron, magnesium and zinc in the digestive tract to form insoluble salts, thereby decreasing or reducing bioavailability or absorption of nutrients. Dietary tannins (in excess) are known to reduce feed efficiency and weight gain in chicks [40]. Saponins have haemolytic activity against RBC [41]. In this study, the seeds' flours examined contain appreciable amount of phytochemicals. There was a significant difference among all the samples ( $\mathrm{p} \geq 0.05$ ) in all the phytochemical determined. Saponin was higher in Moringa seed's flour (1.368\%) follow by pear and watermelon seeds' flours which means their saponin contents compared favourably with the report of [42] on watermelon seed. Table 3 shows that the tested seeds' flour most especially watermelon seed's flour follow by pear and benoil seeds' flours are rich in flavonoids. Flavonoids have been reported to possess substantial anti-carcinogenic and anti-mutagenic activities due to their anti-oxidant, antiinflammatory properties and also active in reducing high blood pressure [43, 44]. Alkaloids are widely used as basic medicinal agents for their analgesic, antispasmodic and bactericidal effect [45]. The alkaloid content of the seeds' flours was also recorded to be high generally most especially in watermelon seed's flour but lower than the one obtained for watermelon seeds by [42]. The cyanide content was generally very low $(0.052-0.078 \%)$ in all the seeds' flours examined which is a good indication that they when these seeds' flours are consumed, they will not bind essential minerals or reduce the absorption of nutrients.

Table 3. Result of the Phytochemical contents of benoil, watermelon, pear, pawpaw and melon seeds'flours.

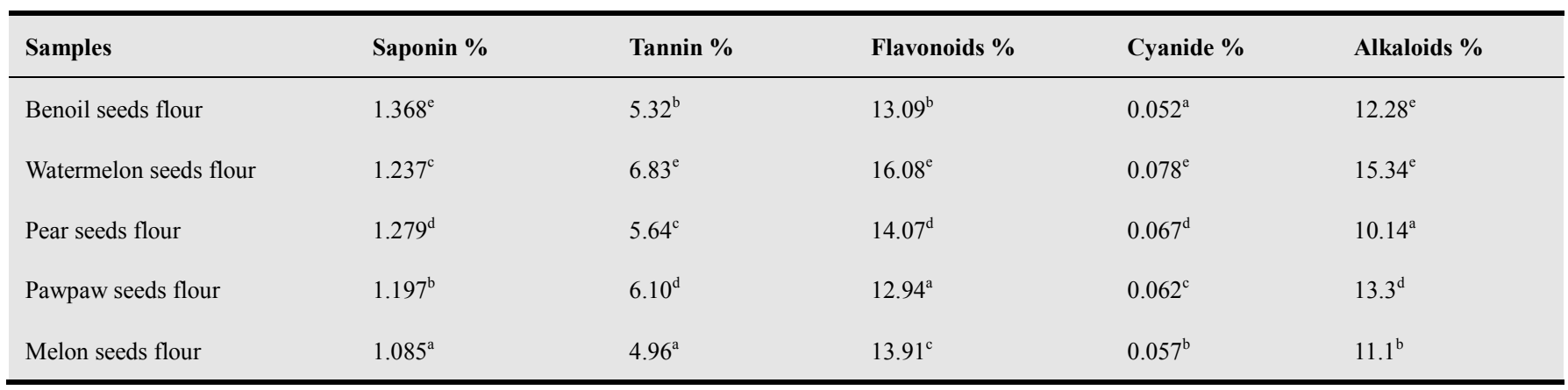

* Values are means of triplicate determination

* Means on the same column with different superscripts are significantly different $(\mathrm{P} \leq 0.05)$ 


\subsection{Result of the Functional Properties of Ben Oil (Moringa oleifera), Pawpaw, Watermelon, Pear Seed and Melon Seeds' Flours}

Functional properties (solubility, foamability, gelation and emulsification properties etc.) are the intrinsic physicochemical characteristics which may affect the behaviour of food systems during processing and storage. Adequate knowledge of these physicochemical properties indicates the usefulness and acceptability for industrial and consumption purpose [46]. Water absorption capacity (WAC) of the sample ranged from 195.51 to $296.77 \%$ (table 4 ).

Higher values were recorded for water melon, pear and pawpaw seeds' flours in terms of water absorption capacity (i.e. ability of a product to associate with water under a condition where water is limiting) while lower values were recorded for benoil and melon seeds' flours.

The bulk density tapped and untapped ranged from 0.347 to $0.533 \mathrm{gcm}^{-3}$ and 0.284 to $0.404 \mathrm{gcm}^{-3}$ respectively. Also, higher values were recorded for watermelon, pear and benoil seeds' flours in terms of bulk density (both tapped and untapped) while the values were low in the rest. The high value compared favourably with the report of [47]. This may be related to the fact that these seeds' flours may be high in protein. The decreased in water absorption capacity and bulk density contents shows that a good weaning food could be produced with the seeds' flours According to [48], lower water absorption capacity is desirable for making thinner gruels with high caloric density per unit volume. Also according to [49], low bulk density is an advantage because high bulk limits the caloric and nutrient intake per feed per child and infants sometimes are unable to consume enough to satisfy their energy and nutrient requirements. Bulk density is also important in the packaging requirement and material handling of a product [50]. The decrease in loose and packed densities in some of the seeds' flours shows that it is an advantage since according to [50], a large free space is undesirable in packaging of foods because it constitute a large oxygen reservoir, whereas a low loose and packed densities results in greater oxygen transmission in packed foods. Solubility is an index of protein functionality such as denaturation and its potential applications [48]. High levels of solubility were observed in benoil and watermelon seeds' flour at temp. between $\left(65\right.$ to $\left.95^{\circ} \mathrm{C}\right)$ this is however in contrast to the result of [48], on the solubility of complementary diets developed from soybean, groundnut and crayfish, whereby increase in solubility was recorded at increased levels of protein which indicate the seeds' may be high in protein content i.e. solubility is an advantage to protein as stated by [48]. Least gelation capacity of the sample ranged from 1.60 to $2.00 \%$ with pear seed's flour having the lowest value and pawpaw sample had the highest value compared to others where there was significant difference $(p<0.05)$ in terms of least gelation capacity. The high level is however desirable since high least gelation concentration will lead to reduction in viscosity which therefore led to increase in nutrient density and low dietary bulk which is highly favourable for a good weaning diet. Regarding oil absorption (which is an indication of aroma and rancidity), high values were observed in almost all the tested seeds' flour as the values obtained were so close (table 4) although a bit higher in pear and pawpaw seeds' flours. It shows the seeds' flour will likely give good aroma and it shows they could be good sources of oil. Swelling capacity at $65^{\circ} \mathrm{C}, 75^{\circ} \mathrm{C}, 85^{\circ} \mathrm{C}$ and $95^{\circ} \mathrm{C}$ ranged from 97.84 to $105.71 \%$, 103.63 to $106 \%, 103.00$ to $105.71 \%$ and 104.82 to $105.89 \%$ respectively.

At $65^{\circ} \mathrm{C}$ watermelon sample had the lowest value and benoil sample had the highest value. At $75^{\circ} \mathrm{C}$ the swelling capacity increased from 103.63 to $106.78 \%$ with pawpaw sample having the lowest value and melon sample having the highest value. At $85^{\circ} \mathrm{C}$ melon seed's flour had the lowest value while pear sample had the highest value. At $95^{\circ} \mathrm{C}$, watermelon sample had the lowest value and pear sample having the highest value.

Table 4. Result of the Functional Properties of Moringa oleifera, Pawpaw, Watermelon, Pear Seed, Melon Seeds' Flours.

\begin{tabular}{|c|c|c|c|c|c|c|}
\hline \multirow{2}{*}{ Sample } & \multirow{2}{*}{ BD tapped $(\mathrm{g} / \mathrm{cm} 3)$} & \multirow{2}{*}{ BD untapped (g/cm3) } & \multicolumn{4}{|c|}{ Swelling \% } \\
\hline & & & $65 \%$ & $75 \%$ & $85 \%$ & $95 \%$ \\
\hline Benoil Seed's flour & $0.533^{\mathrm{e}}$ & $0.305^{\mathrm{b}}$ & $105.71^{\mathrm{e}}$ & $106.60^{\mathrm{d}}$ & $104.90^{\mathrm{d}}$ & $104.82^{\mathrm{a}}$ \\
\hline Watermelon Seed's flour & $0.501^{\mathrm{d}}$ & $0.404^{\mathrm{d}}$ & $92.84^{\mathrm{a}}$ & $105.45^{\mathrm{c}}$ & $103.68^{\mathrm{b}}$ & $104.82^{\mathrm{a}}$ \\
\hline Pear Seed's flour & $0.463^{\mathrm{c}}$ & $0.379^{\mathrm{c}}$ & $100.44^{\mathrm{b}}$ & $104.79^{\mathrm{b}}$ & $105.71^{\mathrm{e}}$ & $105.89^{\mathrm{d}}$ \\
\hline Pawpaw Seed's flour & $0.347^{\mathrm{a}}$ & $0.284^{\mathrm{a}}$ & $105.55^{\mathrm{d}}$ & $103.63^{\mathrm{c}}$ & $104.44^{\mathrm{c}}$ & $105.50^{\mathrm{c}}$ \\
\hline Melon Seed's flour & $0.357^{\mathrm{b}}$ & $0.305^{\mathrm{b}}$ & $104.94^{\mathrm{c}}$ & $106.78^{\mathrm{e}}$ & $103.00^{\mathrm{a}}$ & $105.19^{\mathrm{b}}$ \\
\hline
\end{tabular}

Table 4 (continues)

\begin{tabular}{|c|c|c|c|c|c|c|c|}
\hline \multirow{2}{*}{ Sample } & \multirow{2}{*}{ LG\% } & \multicolumn{4}{|c|}{ Solubility\% } & \multirow{2}{*}{ WAC \% } & \multirow{2}{*}{ OAC \% } \\
\hline & & $65 \%$ & $75 \%$ & $85 \%$ & $95 \%$ & & \\
\hline Benoil Seed's flour & $1.80^{\mathrm{ab}}$ & $20.24^{\mathrm{c}}$ & $4.00^{\mathrm{d}}$ & $1.90^{\mathrm{b}}$ & $1.90^{\mathrm{b}}$ & $195.51^{\mathrm{a}}$ & $271.69^{\mathrm{a}}$ \\
\hline Watermelon Seed's flour & $1.80^{\mathrm{ab}}$ & $2.70^{\mathrm{d}}$ & $3.26^{\mathrm{c}}$ & $2.54^{\mathrm{c}}$ & $2.54^{\mathrm{c}}$ & $296.77^{e}$ & $279.33^{c}$ \\
\hline Pear Seed's flour & $1.60^{\mathrm{a}}$ & $1.75^{\mathrm{b}}$ & $2.50^{\mathrm{b}}$ & $2.02^{\mathrm{b}}$ & $2.02^{\mathrm{b}}$ & $270.34^{\mathrm{d}}$ & $321.34^{\mathrm{e}}$ \\
\hline Pawpaw Seed's flour & $2.00^{\mathrm{b}}$ & $2.41^{\mathrm{c}}$ & $2.35^{\mathrm{b}}$ & $1.45^{\mathrm{a}}$ & $1.45^{\mathrm{a}}$ & $253.04^{\mathrm{c}}$ & $307.27^{\mathrm{d}}$ \\
\hline Melon Seed's flour & $1.80^{\mathrm{ab}}$ & $0.43^{\mathrm{a}}$ & $1.77^{\mathrm{a}}$ & $2.39^{c}$ & $2.39^{\mathrm{c}}$ & $199.60^{\mathrm{b}}$ & $278.19^{b}$ \\
\hline
\end{tabular}

* Values are means of triplicate determination

* Means on the same column with different superscripts are significantly different $(\mathrm{P} \leq 0.05)$ 


\section{Conclusion and Recommendation}

\subsection{Conclusion}

The result of the functional property from this study shows that the seeds' flours examined could be used in infant food formulation. The result also shows that they contain essential nutrients which could be good for human consumption and food processing especially benoil (Moringa oleifera) and pawpaw seed's flour.

Presence of phytochemicals in the seeds' flours indicates possible preventive and curative properties of these studied seeds flours as revealed on the result.

This research work is an indication that great potential exists for the use of watermelon seed, melon seed, benoil, pear and pawpaw seed instead of throwing them away as waste after consuming the pulp.

\subsection{Recommendation}

Further work should be carried out on the effect of drying methods on the qualities of the seeds' flours. Also, effect of their incorporation in food products should be examined

\section{References}

[1] Hussein, A.M.S, Kamil, M.M and Mohammed, G.F (2011). Phytochemical and sensorial quality of Semolina defatted guava seed flours composite pasta. J. Amer. Sc., 7 (6): $623-$ 629

[2] Ajila, C.M., Naidu, K.A. Bhat S.G and Prasada, R (2007) Bioactive compounds and antioxidant Chemists potential of mango peel extract. Food Chem., 105: 982-988

[3] Schieber, A. , Stintizing, F.C and Carle, R (2001). By products of plant food processing as a source of functional compound, recent developments. Trends Food Sci. and Techn., 12(11):401-413

[4] Marfo, E.K., Oke, O.L. and Afolabi, O.A (1986). Some studies on the protein of Carica papaya seeds. Food Chem., 22 (4): 267-277

[5] Imaga, N.O.A, Gbenle, G.O, Okochi V.I, Akanbi, S.O, Edeoghon, S.O, Oigbochie, V., Kehinde M.O and Bamiro S.B (2009). Antisickling property of Carica papaya leaf extract. African J. Biochem. Res., 3:102-106

[6] Okeniyi, J. A.O, Ogunlesi, T.A, Oyelami O.A and Adeyemi L.A (2007). Effectiveness of dried Carica papaya against Human Intestinal parasitosis; a pilot study. J. Med. Food, 10: 194-196

[7] Hertog, M.G., et al. (1995). Flavonoid intake and long-term risk of coronary heart disease and cancer in the seven countries study. Arch Intern Med 155(4): p. 381-6.

[8] Arts, I.C. and Hollman, P.C (2005). Polyphenols and disease risk in epidemiologic studies. Am J Clin Nutr, 81(1 Suppl): p. 317S-325S.

[9] Kushi, L.H, Doyle, C and McCullough, M (2012). American
Cancer Society guidelines on nutrition and physical activity for cancer prevention: Reducing the risk of cancer with healthy food choices and physical activity. CA Cancer J Clin. 62:30-67

[10] Elemo, B.O, Elemo, G.N, Oladimeji, O.O and Komolafe. Y.O (2002). Studies on the composition of some nutrients and anti nutrients of Sheanut (Butyrospernum parkii). Niger. Food J. 20: 69-73.

[11] Adekunle, V.A.J and Ogerinde, O.V (2004). Food Potentials of some indigenous wild fruit in lowland rainforests ecosystem of south west Nigeria. J. Food Technol. 2: 125-130

[12] AOAC (2000). Official methods of analysis, Association of Official Analytical Chemists. 15th Ed., Arlinton, VA, USA

[13] Egan, H., Kirk, S.K. and Sawyer, R (1981). Pearson's chemical analysis of foods (8th edition). Longman Group Ltd.

[14] Harborne, J.B. (1973). Phytochemical Methods: A Guide to Modern Techniques of plant Analysis. Chapman and Hall Ltd., London. P. 27

[15] Sathe, S.K., Desphande, S.S. and Salunkhe, D.K. (1982). Functional properties of Lupin seed (Lipinus mutabilis) Protein and protein concentrates. Journal of food Science 47:491-497.

[16] Leach, H.W., McCowen L.D. and Scoch, T.J. (1959). Structure of starch granule, swelling and solubility patterns of various starches. Cereal Chemistry 36: 534-544.

[17] Akpapunam, M.A. and Markakis, P. (1987). Physiochemical and nutritional aspects of Cowpea flour. Journal of food Science 46: 972-973

[18] Coffman, C.W. and Garcia, V.V. (1977). Functional properties of flours prepared from Chinese indigenous legume seed. Food Chemistry 61: 429-433.

[19] Pugalenthi, M., Vadivel, V., Gurumoorthi, P. and Janardhanan (2004). Comparative nutritional evaluation of little known legumes, Tamarindus indica, Erythrina indica and Sesbania bispinosa. Trop. Subtrop. Agroecosyst. 4: 107-123.

[20] Ojokoh, A.O., and Lawal, R.T (2003). Changes in nutrient content of popcorn and groundnut composite flours subjected to solid substrate fermentation, Int. J. Tropical Med. \& Pub. Health, Vol. 1 Issue 1, 50-53.

[21] Nzikou, J.M., Mate, L., Bouanga-kalou, G., Ndangui, C.B., Pambou-Tobi, N.P.G., Kimbonguila, A., Silo, T., Linder, M and Desobry, S (2009). Chemical composition of the seeds and oil of sesame (Sesamun indicum L.) grown in CongoBrazzaville. Advance Journal of food Science and Technology, 1(1), 6-11

[22] Hassan, L.G., Sanni N.A., Dangoggo, S.M and Ladan M.J (2008). Nutritional value of bottle gourd (Lagenaria siceraria) seeds. Global J. Pure \& Applied Sci., Vol.4 No. 3, 301-306.

[23] Dreon, D.M, Vranizan, K.M, Krauss, R.M, Austin, M.A and Wood, P.D (1990). The effects of polyunsaturated fat and monounsaturated fat on plasma, Lipoproteins. J. Am. Med. Assoc. 263: 2462.

[24] Galal, I.M.I (1992). Chemical valuation and utilization of some wastes from canning Industry, M.Sc. thesis, Faculty of Agriculture Ain University, Cairo Egypt, pp: $36-40$ and 46-48 
[25] Mabaleha, M.B., Mitei, Y.C. and Yeboah, S.O (2007). A comparative study of the properties of selected melon seed oils as potential candidates for development into commercial edible vegetable oils. J. Am. Oil Chem. Soc., 84:31-36

[26] Alobo, A. (2003). Proximate composition and components in soybean foods and selected functional properties of defatted papaya (Carica papaya L.) kernel flour. Plant Foods for Hum. Nutr., 58: 1-7.

[27] Eromosele, I.C and Eromosele, C.O (1993). Studies on the chemical composition and physio-chemical properties of seeds of some wild plants: (Netherland) Plant Food Hum. Nutr. 43: 251-258.

[28] Adebisi, G.A. and Olagunju, E.O (2011). Nutritional potential of the seed of fluted pumpkin (Telfairia occidentalis), Journal of New Trends in Science and Technology Application, Vol. 1 No $1,7-18$.

[29] Bello, M. O., Falade, O. S., Adewusi, S. R. A. and Olawore, N O (2008). Studies on the chemical compositions and anti nutrients of some lesser known Nigeria fruits. African Journal of Biotechnology Vol. 7 (21), pp. 3972-3979

[30] Arawande, J.O. and Borokini, F.B (2010). Comparative study on chemical composition and functional properties of three Nigerian legumes (Jack beans, pigeon pea and cowpea), J. Emerging Trends in Engineering and Applied Sciences (JETEAS) 1 (1), 89-95

[31] FAO (1970). Amino acid contents of foods and biological data on protein, Food policy and food science service, 72.

[32] FAO (1982). Food composition table for the near East nuts and seeds, FAO food and nutrition paper, 26, 85.

[33] Eka, O.U (1987). Evaluation of nutritive value of feed for growing broilers in Northen Nigeria. Niger. J. Sci. 21: 52-54.

[34] Adewusi, S.R.A, Udio, A.J, and Osuntogun, B.A (1995). Studies on the Carbohydrate Content of Breadfruit (Artocarpus communis Forst) from South-Western Nigeria. Starch Nutr. 85: 289-294.

[35] Olaofe O and Akogun, O.O (1990). Mineral and Vitamin C content and their distribution in some fruits. Niger. Food J. 8: 111

[36] Oluyemi, E.A, Akinlua, A.A, Adenuga, A.A and Adebayo, M.B (2006). Mineral Contents of some commonly consumed Nigerian foods. Sci. Focus.11(1): 153-157.

[37] National Health and Medical Research Council (NHMRC) (1991). Recommended Dietary intakes for use in Australia. Australian Government Publishing Service, G.P.O. Box 84, and Canberra ACT2601
[38] Soetan, K.O and Oyewole, O.E (2009). The need for adequate processing to reduce the anti-nutritional factors in animal feeds: a review. Afr. J. Food Sci., 3(9): 223-232.

[39] Ajayi, I.A, Ajibade, O and Oderinde R.A (2011). Preliminary Phytochemical Analysis of some Plant Seeds Res. J. Chem. Sci., 1(3): 58-62.

[40] Armstrong, W.D., Rogler, J.C and Featherston, W.R (1974). Effects of Tannins Extraction on the performance of Chicks fed Bird resistant Sorghum grain diets. Poult. Sci., 53: 714720 .

[41] Khalil, A.H and Eladawy, T.A (1994). Isolation, Identification and Toxicity of Saponins from different legumes. Food Chem., 50(2): 197-201.

[42] Oseni, O.A. and Okoye, V.I. (2013). Studies of Phytochemical and Antioxidant properties of fruits of Watermelon. J. of Pharmaceutical and Biomedical Sci. 27(27): 508-514

[43] Ayinde, B.A, Onwukaeme, D.N and Omogbai, E.K.I (2007). Isolation and characterization of two Phenolic compounds from the stem bark of Musanga cecropioides R. Brown (Moraceae). Acta Pol. Pharm. 64:183-185.

[44] Li-Weber, M (2009). New Therapeutic aspects of flavones: the anticancer properties of Scutellaria and its main active constituents Wogonin, Baicalein and Bacalin. Cancer Treat Rev. 35: 57-68.

[45] Stray, F (1998). The Natural Guide to medicinal Herbs and plants. Tiger book International, London pp 10-25

[46] Fasasi, O.S., Adeyemi, I.A. and Fagbenro, O.A. 2006. Physicochemical properties of Maize-tilapia flour blends. Journal of Food Technology 3 (3): 342-345.

[47] Samir- El Safy, F., Rabab, H., S and Abd El-Ghany, M.E (2012). Chemical and Nutritional Evaluation of Different Seed Flours as Novel Sources of Protein. World J. of Dairy \& Food Sciences 7(1): 59-65

[48] Obatolu, V. A. and Cole, A.H. 2000. Functional property of complementary blends of Soybean and Cowpea with malted or unmalted maize. Food Chemistry. 70: 147-153.

[49] Omueti, O., Otegbayo B., Jaiyeola O. and Afolabi O. 2009. Functional properties of complementary diets developed from Soybean (Glycine max), Groundnut (Arachis hypogea) and Crafish (Macrobrachium spp.). Journal of Environmental, Agricultural and Food Chemistry 8 (8): 563-573

[50] Akubor, P.I. and Chukwu, J.K. 1999. Proximate composition and selected functional properties of fermented and unfermented African oil bean (Pentaclethra macrophylla) seed flour. Plant Foods for Human Nutrition 54: 227-238. 